\title{
KONTRIBUSI PENGGUNAAN JURNAL BELAJAR PADA PEMBELAJARAN MATAKULIAH PERMAINAN BOLABASKET
}

\author{
Fitria Dwi Andriyani dan Eka Novita Indra \\ Fakultas Ilmu Keolahragaan Universitas Negeri Yogyakarta \\ email: fitria.dwi.andriyani@uny.ac.id
}

\begin{abstract}
Abstrak: Tujuan penelitian adalah menginvestigasi kontribusi penggunaan jurnal belajar terhadap proses pembelajaran matakuliah Permainan Bola Basket. Penelitian merupakan penelitian deskriptif dan dilakukan dengan mengaplikasikan jurnal belajar tiap akhir sesi perkuliahan. Subjek penelitian mahasiswa Prodi PJKR FIK UNY yang mengambil matakuliah Permainan Bola Basket yang berjumlah 46 orang. Teknik pengumpulan data dilakukan lewat tugas menulis jurnal dan angket, sedang teknik analisis data lewat teknik deskriptif kualitatif dan deskreptif kuantitatif. Hasil penelitian menunjukkan bahwa subjek penelitian mengakui adanya pengaruh positif penggunaan jurnal belajar (100\%). Sejumlah 95,65\% mahasiswa memiliki pendapat dan perasaan positif terhadap kegiatan menulis jurnal belajar. Mereka menyatakan bahwa kegiatan menulis jurnal memfasilitasi untuk melakukan refleksi diri, mengingat materi, menyadari peningkatan kemampuan, meningkatkan kemampuan untuk memahami materi, memotivasi peningkatan diri, dan meningkatkan pengetahuan. Penggunaan jurnal belajar memberi nilai dan makna positif terhadap proses pembelajaran. Namun, diperlukan strategi khusus untuk mengimplementasikan jurnal belajar supaya dapat memberi manfaat nyata bagi guru dan siswa.
\end{abstract}

\section{Kata kunci: jurnalbelajar, pembelajaran, permainan bola basket}

\section{THE CONTRIBUTION OF THE STUDENTS' JOURNAL TOWARD THE INSTRUCTIONAL PROCESS OF BASKETBALL GAMES COURSE}

\begin{abstract}
The purpose of this study is to investigate the contribution of the students' journal toward the instructional process of Basketball Games Course. This research was a descriptive research and conducted by applying students' journal after the learning process. The research population was students of Class C Prodi PJKR FIK UNY which took part in the Basketball Games course on year 2014/2015. There were 46 students participated in this study. The research instruments were journal writing assignment and questionnaires on writing journal experience. The result revealed that the participants admitted the positive influence of the use of the students' journal (100\%). There were 95.65\% participants having positive perspective toward journal writing. In addition, participants stated that the journal encourages self-reflection, helps them memorize and understands course material, makes them aware of their ability improvement, motivates self-improvement, and increases their knowledge. It can thus be concluded that journal writing has a positive and meaningful value toward the learning process. However, it needs a specific strategy to make use of the journal so that it can give real benefits to teachers and students.
\end{abstract}

Keywords: student's journal, instructional, basketball games course

\section{PENDAHULUAN}

Usaha untuk senantiasa meningkatkan dan mempertahankan mutu dan kualitas pembelajaran adalah hal yang penting untuk mencapai tujuan pembelajaran. Hal ini dapat dilakukan dengan melakukan berbagai inovasi dan evaluasi atas kinerja pembelajaran dari waktu ke waktu. Hamalik (2008:50-52) mengemukakan bahwa pencapaian kualitas pembelajaran yang baik dipengaruhi oleh unsur-unsur dinamis dalam proses belajar, yaitu (1) motivasi siswa, (2) bahan belajar, (3) alat bantu belajar, (4) suasana belajar, dan (5) kondisi subjek belajar. Pertama, motivasi siswa. Perbuatan belajar terjadi karena adanya motivasi yang mendorong seseorang untuk melakukan perbuatan belajar. Motivasi dapat bersumber dari dalam diri siswa yang bersumber dari kebutuhan tertentu atau bersumber rangsangan dari luar sehingga siswa melakukan perbuatan belajar. Motivasi yang muncul karena kebutuhan dari 
dalam diri siswa dianggap lebih baik dibanding rangsangan dari luar. Namun, seringkali motivasi dari dalam tidak ada atau belum timbul sehingga memerlukan rangsangan dari luar agar timbul motivasi belajar.

Kedua, bahan belajar. Bahan belajar adalah hal-hal yang diperlukan untuk mencapai tujuan belajar. Penentuan bahan belajar didasarkan pada tujuan yang hendak dicapai, misalnya berupa pengetahuan, keterampilan, sikap, dan pengalaman lainnya. Bahan belajar dapat berupa buku, diktat, jurnal atau sumber rujukan lainnya. Ketiga, alat bantu belajar. Alat bantu belajar merupakan semua alat yang digunakan untuk membantu siswa agar dapat belajar secara efektif dan efisien. Dengan alat bantu ini maka pelajaran akan menjadi lebih menarik, konkrit, mudah dipahami, hemat waktu dan tenaga, dan hasil belajar menjadi lebih bermakna. Alat bantu belajar dapat berupa bahan tercetak, media visual, media audio, media audio-visual, serta media-media lain yang membantu proses belajar.

Keempat, suasana belajar. Suasana memiliki arti penting bagi kegiatan belajar karena mempengaruhi motivasi, kegiatan, dan keberhasilan belajar siswa. Suasana menyenangkan dapat menumbuhkan kegairahan belajar, sedangkan suasana kacau, ramai, tidak tenang, dan banyak gangguan akan mengganggu kegiatan belajar yang efektif. Karena itu, guru dan siswa dituntut agar menciptakan suasana lingkungan belajar yang baik dan menyenangkan, menantang, dan menggairahkan.

Kelima, kondisi subjek belajar. Kondisi subjek belajar turut menentukan kegiatan dan keberhasilan belajar. Misalnya, siswa dapat belajar dengan baik apabila berbadan sehat, siap melakukan kegiatan belajar, dan memiliki minat belajar. Sementara kondisi siswa yang kurang sehat, kelelahan, belum siap belajar, dan minat belajar rendah akan mempengaruhi kelancaran dan mutu hasil belajar. Para pendidik hendaknya memperhatikan faktor-faktor tersebut agar proses pembelajaran berlangsung optimal.

Terkait aspek motivasi siswa, suasana belajar, dan kondisi subjek belajar; pendidik dapat mengusahakan terkondisikannya hal tersebut dengan baik dengan cara mengetahui keadaan siswa. Namun, acapkali pendidik lebih dominan fokus dengan bahan belajar dan alat bantu belajar sehingga mengabaikan aspek internal siswa ataupun aspek eksternal lingkungan. Dari proses obser- vasi yang dilakukan peneliti, peneliti menjumpai sebagian pendidik yang belum memperhatikan dengan seksama motivasi siswa, suasana belajar, dan kondisi subjek belajar dalam pembelajaran. Pendidik cenderung lebih fokus pada materi yang disampaikan dan menuntut siswa untuk siap mengikuti materi dengan sendirinya tanpa mengetahui kondisi siswa. Akibatnya, pembelajaran tidak dapat berlangsung optimal karena ada faktor terselubung yang mengganggu siswa dalam proses pembelajaran

Selain itu, para siswapun belum tentu mengomunikasikan apa yang dihadapinya dengan baik dalam situasi pembelajaran di kelas. Berdasarkan pengamatan, sebagian mahasiswa masih memiliki kemampuan berkomunikasi kurang. Adakalanya mahasiswa dapat memberikan jawaban atau solusi ketika dihadapkan pada suatu pertanyaan atau permasalahan yang sederhana,tetapi ketika diminta menjelaskan ide atau gagasannya secara komprehensif baik secara lisan maupun tertulis, mahasiswa mengalami kesulitan. Dalam hal ini terjadi masalah dalam proses komunikasi yang dilakukan oleh mahasiswa. Budaya kritis yang masih minim sebagai hasil pendidikan masa lalu yang cenderung memosisikan siswa sebagai objek belajar dan cenderung menerima materi dari guru secara satu arah sangat mempengaruhi kemampuan siswa menyampaikan opini secara langsung. Bahkan, hal tersebut terbawa sampai jenjang perguruan tinggi.

Penggunaan jurnal merupakan suatu alternatif metode yang dapat dilakukan saat pembelajaran berlangsung untuk meningkatkan kemampuan berkomunikasi mahasiswa terutama komunikasi tertulis. Selain itu, penggunaan jurnal dapat digunakan untuk membantu mahasiswa mencapai tujuan pembelajaran secara optimal. Jurnal yang dimaksud adalah suatu catatan tertulis atas partisipasi, hasil, respon, perasaan, persepsi, atau refleksi mengenai kejadian-kejadian atau hasil aktual dalam pembelajaran (Graham, Holt/ Hale, \& Parker, 1998: 177). Jurnal adalah alat untuk merekam ide, pikiran dan pengalaman personal, seperti refleksi dan pandangan siswa dalam proses pembelajaran. Harris, et al (2007) mengemukakan bahwa jurnal adalah alat pengukuran yang didesain untuk mendorong refleksi dan belajar mandiri dan jurnal memberi siswa tanggung jawab untuk mencatat pikirannya mengenai pembelajaran. Penulisan jurnal berdasar pada premis bahwa menulis berkontribusi lebih 
besar terhadap pembelajaran dan keterlibatan siswa dalam mata pelajaran karena menyediakan kesempatan bagi siswa untuk mengklarifikasi dan merefleksikan pikirannya.

Dari beberapa pendapat di atas, disimpulkan bahwa jurnal adalah catatan tertulis siswa yang digunakan untuk merekam ide, pikiran, pengalaman personal, hasil, respon, perasaan, persepsi atau refleksi mengenai hal-hal yang dialami siswa saat pembelajaran. Penggunaan jurnal dilakukan dikarenakan manfaat-manfaat yang dapat diperoleh dari penggunaan jurnal tersebut.

Berbagai artikel kajian ilmiah dan hasil penelitian menunjukkan manfaat-manfaat dari penggunaan jurnal belajar.Dari segi guru, penggunaan jurnal belajar menyediakan kesempatan berharga untuk mengukur afektif siswa melalui kegiatan menulis mengenai kualitas pengalaman belajar yang disediakan oleh guru baik dari segi aktivitas, pendekatan pedagogis, dan proses evaluasi (Cutforth \& Parker, 1996). Selain itu, penggunaan jurnal memungkinkan guru untuk membangun hubungan personal dan dialog dengan siswa (Cutforth \& Parker, 1996; Hopkins, 2010). Penggunaan jurnal menyediakan informasi berguna bagi guru baik mengenai level keterlibatan siswa dalam kegiatan, permasalahan yang dihadapi siswa dalam pembelajaran, maupun tingkat pencapaian personal mengenai apa yang sedang dipelajari (Cutforth \& Parker, 1996). Di samping itu, penggunaan jurnal memungkinkan guru untuk mengetahui pendapat siswa mengenai pembelajaran yang dilakukan dan sebagai bahan perbaikan dalam mengajar selanjutnya (Hopkins, 2010).

Sementara dari segi siswa, penggunaan jurnal belajar bermanfaat untuk: (1) meningkatkan keterampilan menulis siswa (Hopkins, 2010), (2) memungkinkan siswa untuk merefleksikan penampilannya dalam pembelajaran, mengetahui kelebihan dan kekurangannya, dan bagaimana rencana siswa untuk memperbaiki penampilannya (Harris, et al, 2007), (3) memberikan manfaat dari sisi kognitif(meningkatkan pemahaman terhadap materi) dan afektif(Jurdak \& Zein, 1998), dan (4) meningkatkan kemampuan berpikir kritis (Hooey \& Bailey, 2005).

Meskipun terdapat banyak pendapat dan studi yang menunjukkan berbagai manfaat penggunaan jurnal dalam pembelajaran, namun secara kontras, beberapa studi dan kajian memaparkan mengenai kurang bermaknanya penggunaan jurnal dalam peningkatan kognitif siswa (Mills, 2008). Penggunaan jurnal dilaporkan tidak membawa pengaruh signifikan pada persepsi mahasiswa terhadap pembelajaran yang diikuti oleh kelompok eksperimen dibandingkan kelompok kontrol (Kotsokalis, 2008). Laporan lain menyebutkan bahwa penggunaan jurnal tidak membawa pengaruh signifikan terhadap keterampilan berpikir kritis mahasiswa (Zurmehly, 1999).

Berdasarkan dua pandangan kontras mengenai kebermaknaan dan ketidakbermaknaan penggunaan jurnal bagi siswa dan guru, penelitian ini bermaksud untuk mengungkap kontribusi penggunaan jurnal belajar dari perspektif mahasiswa. Hal tersebut dilakukan untuk: (1) mengetahui kontribusi jurnal dalam proses pembelajaran mahasiswa dan (2) sikap dan pendapat siswa mengenai penggunaan jurnal dalam pembelajaran.

\section{METODE}

Penelitian ini adalah penelitian deskriptif dengan tujuan untuk menggambarkan kontribusi penggunaan jurnal belajar dalam matakuliah Permainan Bola Basket dari perspektif mahasiswa. Subjek penelitian adalah mahasiswa PJKR FIK UNYyang mengikuti matakuliah Permainan Bola Basket yang berjumlah 46 orang mahasiswa.

Teknik pengumpulan data adalah penugasan menulis jurnal dan kuesioner. Pada awal semester, mahasiswa diminta menyiapkan buku khusus untuk menjawab pertanyaan sebagai buku jurnal belajar selama satu semester. Buku jurnal belajar dikumpulkan pada akhir tiap pertemuan untuk dikoreksi dan diberi umpan balik oleh dosen dan diambil kembali sebelum pembelajaran dimulai pada pertemuan berikutnya. Pada akhir semester, buku jurnal belajar dikumpulkan untuk proses analisis data. Pada akhir semester, diberi kuesioner tentang pengalaman menulis jurnal. Teknik analisis data yang digunakan adalah analisis deskriptif kualitatif untuk menggambarkan kontribusi penggunaan jurnal belajar berdasarkan perspektif mahasiswa dan deskriptif kuantitatif lewat penghitungan persentase.

\section{HASILDAN PEMBAHASAN Hasil}

Berdasarkan pengumpulan data melalui kuesioner, didapatkan hasil sebagai berikut. Pertama, semua partisipan (100\%) mengemukakan bahwa kegiatan menulis jurnal memberi pengaruh positif dalam belajarmata kuliah Permainan Bo- 
labasket. Kegiatan menulis jurnal merupakan hal yang baru bagi partisipan, seperti yang diungkapkan oleh CHY (bukan nama sebenarnya) berikut:

"Jurnalnya berguna untuk menambah/mengasah pengetahuan saya. Dapat pengalaman baru sebagai bahan untuk mendidik anak didik di waktu yang akan datang".

Kegiatan menulis jurnal memberi kesempatan bagi mahasiswa untuk merefleksikan perkembangan kemampuan keterampilannya dari waktu ke waktu. Mahasiswa dapat menilai sendiri kelebihan dan kelemahan atau kekurangannya dalam pembelajaran sehingga dapat melakukan koreksi dan perbaikan penampilan dalam pembelajaran dan permainan. Koreksi tertulis dari dosen juga membantu pada proses ini. Dokumentasi jurnal memberi kesempatan bagi siswa untuk menilik kembali apakah tujuan-tujuan yang telah ditetapkan di awal perkuliahan tercapai atau belumdari waktu ke waktu. Hal ini seperti diungkapkan oleh beberapa mahasiswa berikut.

$\mathrm{AH}$ : "Dalam penulisan jurnal saya dapat mengetahui kekurangan saya dalam bermain dan koreksi dosen dapat dijadikan masukan agar dapat memperbaiki”.

AP : "Kegiatan menulis jurnal membantu saya dalam proses pembelajaran. Melalui kegiatan tersebut proses pembelajaran yang telah kita lakukan terekam secara tertulis dan dapat mengevaluasi kekurangan dalam pembelajaran tersebut".

Selain itu, kegiatan menulis jurnal berperan sebagai media bagi mahasiswa untuk menyampaikan permasalahan-permasalahan yang dialami dalam pembelajaran dan situasi permainan secara langsung kepada dosen. Karena bersifat privat, mahasiswa cenderung lebih terbuka dalam mengemukakan permasalahannya. Situasi menjadi berbeda jika dalam pembelajaran karena bisa jadi merasa malu sehingga tidak mengungkapkan permasalahan atau karena keterbatasan waktu pembelajaran sehingga tidak mungkin untuk menampung semua permasalahan siswa secara lisan dan langsung dalam situasi pembelajaran. Melalui jurnal, mahasiswa mendapat masukan dan saran secara privat dari dosen. Situasi seperti itu dapat menumbuhkan komunikasi yang baik antara mahasiswa dan dosen. Hal ini seperti diungkapkan mahasiswa sebagai berikut:
IMW: "(Kegiatan menulis jurnal) sangat berpengaruh karena dengan menulis jurnal kita bisa mengingat danjuga dapat menyampaikan kepada ibu dosen masalah-masalah yang kita dapat ketika pembelajaran berlangsung. Dan juga jurnal dapat mendekatkan komunikasi peserta didik dengan ibu dosen".

MG: "Adanya jurnal saya dapat menuliskan kesulitan yang saya hadapi dalam pembelajaran karena terkadang malu menanyakan secara langsung".

Hasil kedua, sejumlah 95,65\% partisipan kelompok perlakuan memiliki pendapat dan perasaan positif terhadap kegiatan menulis jurnal. Beberapa mahasiswa menyampaikan bahwa penulisan jurnal agak ribet, namun tidak menafikkan mengenai manfaat dari kegiatan menulis jurnal bagi mereka. Seperti yang dikemukakan oleh MK bahwa penulisan jurnal ribet tapi bermanfaat. Demikian juga KP yang mengemukakan bahwa (penulisan jurnal) awalnya merasa ribet, tapi lama kelamaan merasakan manfaatnya dan dapat digunakan untuk referensi mengajar. Kegiatan menulis jurnal merupakan hal yang cukup asyik dan kreatif karena proses pembelajaran berbeda dengan kelas lain(JC). Hal senada dikemukakan oleh AEN yang mengungkapkan sebagai berikut:

"Ini inovasi baru dari ibu dosen, mungkin belum pernah dilakukan namun makul ini membuat terobosan baru. Perasaan saya senang dalam menulis jurnal dan ketika ada tanggapan dari ibu sangat membangun untuk saya"

Penulisan jurnal membuat mahasiswa menjadi tidak seenaknya kuliah dan memiliki tanggung jawab memperhatikan materi kuliah (YU). Hal ini karena pertanyaan-pertanyaan yang diberikan dosen terkait dengan pembelajaran yang baru saja dilakukan sehingga apabila mahasiswa tidak menyimak dengan baik saat pembelajaran, maka akan kesulitan dalam menjawab pertanyaan. Proses tersebut memicu mahasiswa untuk berkonsentrasi dan mendengarkan penjelasan saat pembelajaran dengan baik. Sementara RDA mengemukakan sisi menarik dari kegiatan menulis jurnal, bahwa penulisan jurnal akan lebih efektif apabila jurnal tidak hanya ditulis saja namun perlu adanya usaha untuk mempelajari jurnal tersebut. 
Hal ini mengungkap sisi lain dari cara mendapat manfaat optimal dari kegiatan penulisan jurnal.

Hasil ketiga, partisipan kelompok perlakuan mengemukakan berbagai manfaat dari kegiatan penulisan jurnal, yaitu: (1) sebagai bahan koreksi diri $(45,65 \%)$, (2) mempermudah mengingat materi kuliah $(36,96 \%)$, (3) mengetahui perkembangan kemampuan $(19,56 \%)$, (4) memberi motivasi peningkatan diri $(13,04 \%)$, (5) lebih memahami materi $(17,49 \%)$, dan (6) Menambah wawasan (6,52\%). manfaat kegiatan menulis jurnal dapat dilihat pada grafik 1 .

Hasil keempat,terkait saran dari kelompok perlakuan agar kegiatan menulis jurnal menjadi lebih efektif, terdapat ragam saran yang diberikan. Sebanyak $19,56 \%$ partisipan menjawab bahwa kegiatan penulisan jurnal sudah efektif. Sementara saran-saran yang masuk yaitu: (1) diberikan reward untuk jurnal terbaik, (2) waktu penulisan jurnal supaya ditambah, (3) pertanyaan supaya ditambah, (4) perlunya memberikan jeda sebelum menulis jurnal, (5) perlunya memperhatikan alokasi waktu saat kegiatan menulis jurnal, (5) perlunya arahan pada mahasiswa agar bersungguh-sungguh dalam mengisi jurnal, (6) tingkat kesulitan pertanyaan agar ditambah, (7) ditambahkan pertanyaan terkait teori, (8) komentar dan tanggapan atas pertanyaan supaya lebih detail, (9) perlunya mahasiswa mempelajari isi jurnal yang ditulis, (10) jawaban jurnal diulas secara rinci di pertemuan berikutnya, dan(11) jurnal harus berisi pertanyaan yang berhubungan dengan materi yang diujikan/dipraktekkan.
Hasil kelima yaitu mengenai ingin atau tidaknya mahasiswa kelompok perlakuan untuk melanjutkan kegiatan menulis jurnal dan didapatkan hasil sebagai berikut. Terdapat sebanyak $95,65 \%$ siswa berpendapat positif dan ingin melanjutkan kegiatan menulis jurnal pada mata kuliah yang lain. Sebanyak 2,17 \% menyatakan "mungkin iya" untuk meneruskan kegiatan menulis jurnal. Sementara $2,17 \%$ menyatakan tidak ingin melanjutkan kegiatan menulis jurnal. Mahasiswa yang menyatakan tidak ingin menyatakan hal tersebut karena memandang dari sudut pandang berbeda yaitu dikarenakan tidak ingin mengulang matakuliah Permainan Bola Basket lagi semester berikutnya.

\section{Pembahasan}

Secara umum, hasil penelitian menunjukkan bahwa kegiatan menulis jurnal memberi pengaruh positif dalam belajar mata kuliah Permainan Bolabasket.Hasil tersebut sejalan dengan hasil penelitian sebelumnya bahwa kegiatan menulis jurnal memberi pengaruh positif terhadap pemahaman konseptual (Jurdak \& Zein, 1998) dan memberikan pengaruh yang signifikan terhadap kemampuan kognitif (Sabilu, 2008; Septiyana, dkk, 2013). Salah satu hal yang mendorong ini dapat terjadi adalah karena kegiatan menulis jurnal membantu mahasiswa kelompok perlakuan dalam mereview materi yang telah diberikan sehingga lebih mudah mengingat materi. Melalui kegiatan penulisan jurnal, siswa dapat melakukan penghubungan antara teori dan praktek,

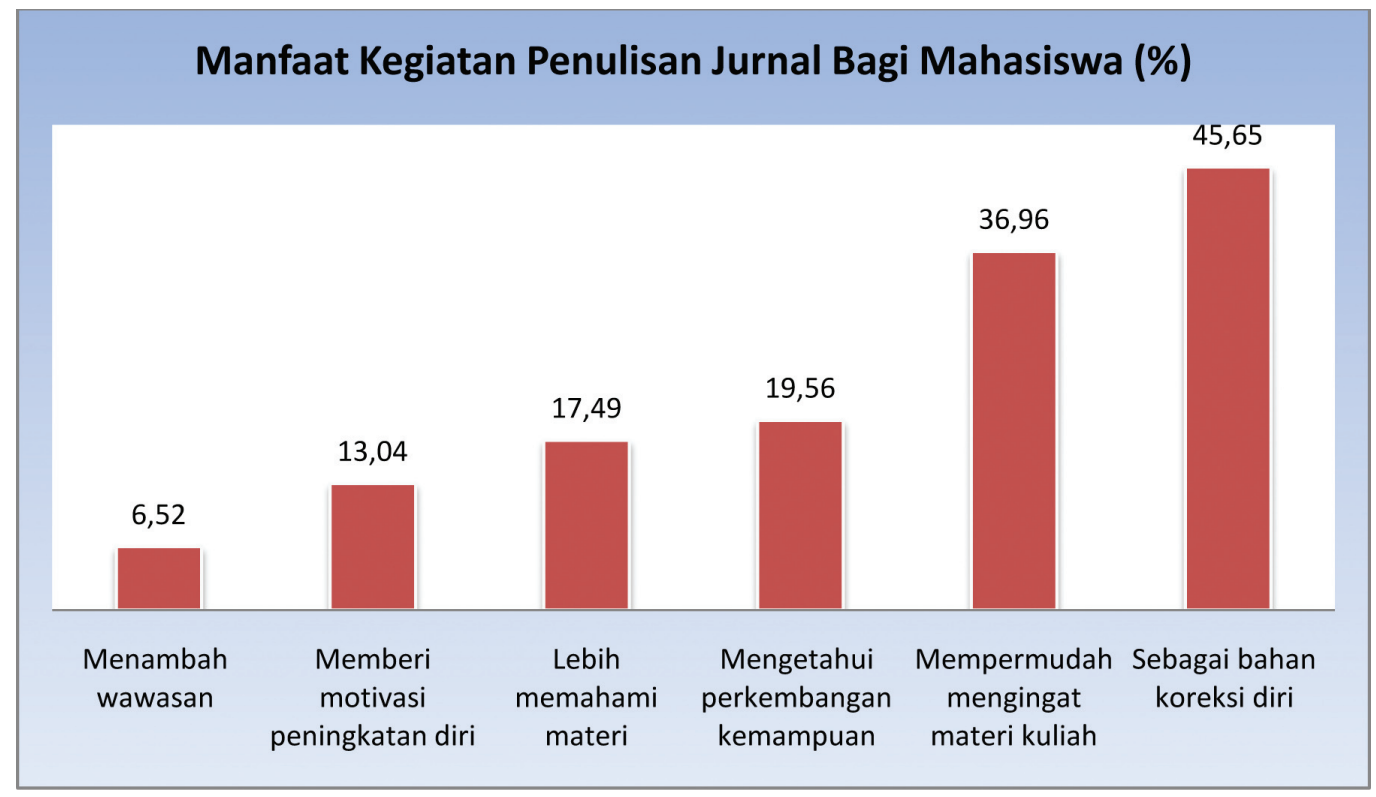

Grafik 1. Manfaat Kegiatan Penulisan Jurnal Bagi Mahasiswa 
kesadaran akan kekuatan dan kelemahan, serta integrasi antara ide-ide dan konsep baru (Langley \& Brown, 2010).

Selanjutnya, mayoritas partisipan berpendapat dan perasaan positif terhadap kegiatan menulis jurnal sehingga mayoritas mahasiswa ingin melanjutkan kegiatan penulisan jurnal. Hal ini terjadi karena mahasiswa mengakui dan merasakan kemanfaatan dari kegiatan menulis jurnal. Seperti halnya pada temuan Picca, Starks, \& Gunderson (2013) yang menunjukkan bahwa respon kualitatif siswa menunjukkan keefektifan kegiatan penulisan jurnal guna mencapai tujuan pembelajaran. Hal ini sejalan dengan temuan Harris, et al. (2007) bahwa kegiatan penulisan jurnal memungkinkan siswa untuk merefleksikan penampilannya dalam pembelajaran, mengetahui kelebihan dan kekurangannya, dan merencanakan cara untuk memperbaiki penampilannya.

Di samping itu, peneliti merasakan manfaat nyata atas terbangunnya hubungan interpersonal yang lebih baik dengan mahasiswa melalui kegiatan penulisan jurnal. Hal ini karena peneliti dapat berkomunikasi dan mengetahui perasaan mahasiswa selama mengikuti pembelajaran. Kegiatan penulisan jurnal membantu mengungkap perasaan pribadi mahasiswa, seperti rasa malu, capek, kurang percaya diri, kurang semangat, dan lain-lain. Peneliti juga dapat mengetahui tingkat keterlibatan mahasiswa dalam pembelajaran dan perasaan mahasiswa atas pencapaiannya dalam pembelajaran. Hal ini dapat terungkap melalui pertanyaan seberapa besar usaha mahasiswa dalam pembelajaran dan hasil yang dicapai dalam pembelajaran. Selain itu, mahasiswa menjadi lebih terbuka karena terhindar dari rasa sungkan dan/ malu untuk mengungkapkan permasalahan saat kuliah berlangsung. Hal ini dikonfirmasi dari pernyataan mahasiswa pada respon kualitatifnya mengenai kegiatan penulisan jurnal. Dosen pun lebih leluasa dalam memberikan tanggapan dan saran karena tidak keterbatasan waktu kuliah untuk menanggapi semua pertanyaan mahasiswa. Manfaatnya yaitu, bahwa mahasiswa menjadi lebih serius, semangat, dan termotivasi untuk belajar.

Hal tersebut sejalan dengan hasil penelitian Korgel (2002) bahwa kegiatan penulisan jurnal meningkatkan dialog antara guru dan siswa dan memunculkan diskusi dalam kelas yang seringkali berkembang dengan baik di luar area penulisan jurnal. Hasil tersebut juga mendukung pernyataan dari Cutforth \& Parker (1996) dan Hopkins (2010) bahwa kegiatan penulisan jurnal memungkinkan guru untuk membangun hubungan personal dan dialog dengan siswa. Selain itu menyediakan informasi berguna bagi guru baik mengenai level keterlibatan siswa dalam kegiatan, permasalahan yang dihadapi siswa dalam pembelajaran, maupun tingkat pencapaian personal mengenai apa yang sedang dipelajari (Cutforth \& Parker, 1996)

Dalam penulisan jurnal, peneliti mendapat manfaat tambahan berupa refleksidan perbaikan atas pembelajaran yang dilakukan berdasar pendapat mahasiswa. Seperti yang dikemukakan oleh Hopkins (2010) bahwa kegiatan penulisan jurnal memungkinkan guru untuk mengetahui pendapat siswa mengenai pembelajaran yang dilakukan dan sebagai bahan perbaikan dalam mengajar.

Secara kontras dari hasil-hasil positif yang ditemukan dalam penelitian ini, terdapat penelitian-penelitian yang menunjukkan mengenai kurang bermaknanya penggunaan jurnal dalam pembelajaran. Misalnya, Kotsokalis (2008) yang melaporkan bahwa penggunaan jurnal tidak membawa pengaruh signifikan pada persepsi mahasiswa terhadap pembelajaran yang diikuti oleh kelompok eksperimen dibandingkan kelompok kontrol. Laporan lain menyebutkan bahwa penggunaan jurnal tidak membawa pengaruh signifikan terhadap keterampilan berpikir kritis mahasiswa (Zurmehly, 1999). Siswa memang mengakui adanya manfaat dari penulisan jurnal, namun sebagian siswa justru berpendapat bahwa penulisan jurnal tidak penting untuk merefleksikan diri ataupun berpikir kritis;bahkan sebagian siswa menganggap penggunaan jurnal sebagai hal yang mengganggu, tidak penting, dan menyibukkan (Komara dan Hearn dalam Mills, 2008).

Cisero (Mills, 2008) mengungkapkan bahwa hal tersebut terjadi bukan karena penggunaan jurnal yang tidak bermanfaat, namun lebih kepada siswa yang kurang menggunakan jurnal sebagai bahan untuk merefleksikan diri dan mengambil pelajaran darinya. Lebih lanjut dijelaskan bahwa penggunaan jurnal dapat meningkatkan penampilan siswa hanya jika siswa berusaha terlibat secara aktif dalam kegiatan refleksi diri sehingga membuat pelajaran lebih bermakna. Oleh karena itu peran aktif dosen (pendidik) sangat penting dalam mengkondisikan mahasiswa terkait kegiatan menulis jurnal.

Mengenai kontras pendapat mengenai bermakna dan kurang bermaknanya kegiatan menulis 
jurnal, peneliti berada pada posisi bahwa kegiatan menulis jurnal bermakna positif dan bermanfaat bagi proses pembelajaran. Pernyataan ini muncul berdasarkan fakta-fakta temuan di lapangan yang mendukung dari hasil penelitian. Namun, peneliti mengakui bahwa diperlukan strategi khusus supaya kegiatan menulis jurnal membawa manfaat nyata bagi dosen (pendidik) maupun mahasiswa (peserta didik). Kegiatan penulisan jurnal tanpa perencanaan yang matang dan tujuan yang jelas tidak akan membawa pada manfaat yang berarti. Oleh karena itu, diperlukan juga masukan dan saran dari mahasiswa supaya kegiatan penulisan menjadi semakin bermakna seperti yang dilakukan pada penelitian ini. Berdasarkan hal tersebut, berikut ini akan dipaparkan mengenai rekomendasi cara penggunaan jurnal dalam pembelajaran.

\section{SIMPULAN}

Kegiatan menulis jurnal bermakna positif dan bermanfaat bagi proses pembelajaran. Namundiperlukan strategi khusus supaya kegiatan menulis jurnal membawa manfaat nyata bagi pendidik dan peserta didik. Pendidik dapat mengintegrasikan penggunaan jurnal belajar dalam proses pembelajaran guna mendukung proses belajar mahasiswa. Hal ini akan mendukung tercapainya tujuan pembelajaran dengan hasil belajar yang optimal dan terciptanya hubungan interpersonal yang baik antara pendidik dan peserta didik.

Keterbatasan dari penelitian ini yaitu belum mengkaji korelasi antara pendapat siswa dalam kuesioner dengan hasil belajar siswa. Saran untuk penelitian selanjutnya yaitu untuk menginvestigasi kebermanfaatan jurnal belajar dengan sampel yang lebih besar dan dengan mengkorelasikan pendapat partisipan dengan hasil belajar.

\section{UCAPAN TERIMA KASIH}

Ucapan terima kasih disampaikan kepada sejawat dan semua pihak yang telah membantu penelitian ini. Mudah-mudahan semua itu diperhitungkan sebagai amal yang bernilai pahala. Amin.

\section{DAFTAR PUSTAKA}

Cutforth, N., Parker, M. 1996. Promoting affective development in physical education: The value of journal writing. Journal of Physical Education, Recreation \& Dance; Sep 1996; 67, 7; ProQuest Education Journals pg.19.
Graham, G., Holt/Hale S.A., \& Parker, M. 1998. Children Moving: A Reflective Approach to Teaching Physical Education-4th ed. California: Mayfield Publishing Company.

Hamalik, Oemar. 2008. Kurikulum dan Pembelajaran. Jakarta: Bumi Aksara.

Harris, K-L., Krause, K., Gleeson, D., Peat, M., Taylor, C. \& Garnett, R. 2007.Enhancing Assessment in the Biological Sciences: Ideas and resources for university educators.www.bioassess.edu.au. Diakses pada 8 April 2014.

Hooey, Catherine A., Bailey, Timothy J. 2005. Journal Writing and the Development of Spatial Thinking Skills.The Journal of Geography; Nov/Dec 2005; 104, 6; ProQuestpg. 257.

Hopkins, G. 2010. Journal Writing Every Day: Teachers Say It Really Works! http:// www.educationworld.com/a_curr/curr144. shtml\#sthash.XBKqSBeT.dpuf. Diakses pada 8 April 2014.

Jurdak, M., Rihad Abu Z. 1998. The effect of journal writing on achievement in and attitudes toward mathematics.School Science and Mathematics; Dec 1998; 98, 8; ProQuest Education Journals.pg. 412.

Korgel, B. A.2002. Nurturing Faculty-Student Dialogue, Deep Learning And Creativity Through Journal Writing Exercises. Journal of Engineering Education; Jan 2002; 91, 1; ProQuest.pg. 143.

Kotsokalis, Louise M. 2008. The Effects of Journaling on ThePerception of The Overall Course Experience of Community College Nursing Students.Dissertation. Charlotte: University of North Carolina.

Langley, M. E. \& Brown, S. T. 2010.Perceptions of the Use of Reflective Learning Journals in Online Graduate Nursing Education. Nursing Education Perspectives.31.1.(Jan/ Feb 2010): 12-7. 
Mills, Roxanne. 2008. "It's Just A Nuisance": Improving College Student Reflective Journal Writing. College Student Journal; Jun 2008; 42, 2; ProQuest Education Journals. pg. 684 .

Picca, L. H., Starks, B., Gunderson, J. 2013. "It Opened My Eyes": Using Student Journal Writing to Make Visible Race, Class, and Gender in Everyday Life. Teaching Sociology.41(1) 82 -93.DOI: 10.1177/0092055X12460029.

Sabilu, M. 2008. Pengaruh Penggunaan Jurnal Belajar dalam Pembelajaran Multistrategi terhadap Kemampuan Kognitif dan Meta- kognitif Siswa SMA Negeri 9 Malang. Malang: Disertasi dan Tesis Program Pascasarjana UM.

Septiyana, K. dkk.2013. Jurnal Belajar Sebagai Strategi Berpikir Metakognitif Pada Pembelajaran Sistem Imunitas. Unnes Journal of Biology Education.2 (1).

Zurmehly, J. 1999. The Effects of Journaling on The Critical Thinking Skills of Second Year Associate Degree Nursing Student. Master Thesis. Louisville: Program of Graduate Nursing, Allan \& Donna Lansing School of Nursing. 